CAREER VALUES AND PROACTIVE CAREER BEHAVIOUR

\title{
Career values and proactive career behaviour among contemporary higher education students
}

\begin{abstract}
The paper draws on evidence from a survey of Australian and UK students ( $N=433$ ) on students' career values and their relationship to their proactivity in career self-management. Much of the dominant approaches to careers have focused on career competencies and adaptability in the context of increased movement from traditional to more self-managed career trajectories. Limited attention has been given to the role of career values in shaping individuals' approaches to career management, particularly among higher education students. This study reveals data on a range of career values among students on a continuum between intrinsic and extrinsic careers. It revealed a preponderance of intrinsic career values and a clear relationship emerged on the strength of career values and levels of proactivity towards career management. Further, higher levels of intrinsic and extrinsic career values were reported for certain student groups. The article discusses the implications of these data for enhancing students' career planning and engagement.
\end{abstract}

\section{Keywords}

Career values; proactivity; career self-management; intrinsic values; extrinsic values. 


\section{Introduction}

The values prioritised by individuals determine their career decision-making (Cochran 1983), career choice (Judge and Bretz 1992) and career outcomes (Johnson and Mortimer 2011). Sortheix et al. (2013) argued that the most accepted classification of career values is the distinction between intrinsic and extrinsic career values, the latter focused on salary, promotion (reward), employment prospects and security and intrinsic career values on 'the interest, the learning possibilities and the feeling that the career is in accordance to the self' (468). Being values-driven features as one of the two central elements of the protean career orientation, the other self-directed career behaviour (Briscoe and Hall 2006), and means internal values motivate and guide career priorities and decision-making. Extant literature indicates that - to varying degrees - undergraduates are values-driven (Jackson and Wilton 2016; Rojewski, Pisarik, and Han 2017). The distinction in career values overlaps with related career literature on 'objective’ and 'subjective’ career success - the former concerned with observable markers of career outcomes (pay, status, promotion), the latter with more substantive areas such as autonomy, job satisfaction and creative input (Heslin 2005).

How contemporary higher education (HE) students have internalised career values may help us to understand their career motivations, goals and achievements. Intrinsic career values, for example, are positively associated with greater investment towards work (Dietrich, Shulman, and Nurmi 2013), proactivity (Quigley and Tymon 2006), enhanced career outcomes (Ng, et al. 2005) and may lead to improved person-job fit, most likely through careful crafting of their role to personal values (Sortheix, Chow, and Salmela-Aro 2015). For example, Bridgstock’s (2011) study of Creative Arts graduates found that intrinsically motivated graduates predicted stronger career management competence, subjective career success and higher income. Johnson and Monserud (2010) reported intrinsic values were related to higher intrinsic work rewards 
(autonomy, interesting roles, opportunity for professional development) while extrinsic values were associated with greater job security and higher income, although Johnson and Mortimer (2011) assert this is attributed to working longer hours. Conversely, extrinsic career values have been associated with heightened anxiety, lower levels of well-being and reduced job satisfaction, and the focus on reward leading to higher levels of employment but weaker personjob fit (Sortheix et al. 2015).

Increasing prevalence of intrinsic career values and the importance of personal needs and goals means 'companies may no longer be able to offer upward, linear career mobility to motivate and retain individuals' (Bravo et al. 2017, 503). This suggests the need for employers to understand motivating values to design roles that engage and retain new talent. Educators must also ensure that students have the career management capabilities to understand and establish their career goals and effectively identify suitable career opportunities and navigate career pathways to achieve their own definition of career success. It is therefore important to develop greater understanding of the extent to which HE students demonstrate intrinsic and extrinsic values. Given the diversity within the student population, exploring how values are shaped by individual characteristics is important for those responsible for career development learning.

Quigley and Tymon (2016) acknowledge that career values, both intrinsic and extrinsic, are importance influences on career behaviour and decision-making. In particular, they emphasise the theory of intrinsic motivation which asserts the positive influence of meaningfulness, feelings of choice, competence to realise goals, and accomplishing progress on career selfmanagement. Career proactivity, an important element of career self-management, is where an individual takes responsibility and initiative and actively promotes their career (Seibert, Kramer, and Crant 2001). The relationship between careers values and proactivity, and how 
this may vary among student groups, does not appear to be widely explored. Building on existing empirical studies in this area will inform career counsellors and educators on ways to enhance student employability and ultimately improve graduate career outcomes.

Understanding what motivates HE students and their priorities in terms of career goals will inform educators and career practitioners within HE institutions on how to best support students in preparing for their careers, as well as identify effective ways to gauge student success with respect to career readiness and success. The study aimed to answer two broad research questions. First, what are the career values of contemporary HE students and how do they vary with individual characteristics (such as age, gender and discipline). Second, what shapes career proactivity among HE students and to what extent is this driven, if at all, by students' career values? To explore these questions, survey data were gathered from students in two universities, one in Australia and one in the UK. The paper is structured to first provide a review of relevant literature, followed by methodology and the presentation of results. Findings are discussed, implications for stakeholders presented and the paper concludes with an outline of limitations and directions for future research.

\section{Background}

\section{Career values}

National surveys of graduate outcomes provide an indication of the career success of individual students in different disciplines and form an increasingly popular performance metric for HE institutions (Jackson and Bridgstock 2018). Jackson and Bridgstock assert that many, however, remain focused on short-term, full-time graduate employment outcomes, such as Australia's Graduate Outcomes Survey (Social Research Centre 2018), which do not align with contemporary work arrangements and represent transition to the labour force, rather than a 
reliable measure of career success. Acknowledging subjective determinants of success and the realisation of intrinsic career values is crucial, affirmed by Jackson and Bridgstock (2019) who found that job interest and enjoyment - rather than extrinsic factors - rated the highest among their 510 surveyed graduates when defining career success. This is evidenced in, for example, the UK's new national student survey instrument that explores the sense of meaningfulness and importance of current work to the individual, as well as the degree of fit with their career goals (Higher Education Statistics Agency 2017). Recent discussions on the massification, vocationalisation and commodification of HE (see Tight, 2019) also connect with critical concerns about the reduction of its purpose to whether graduates successfully obtain full-time employment shortly after graduation.

There has been some exploration of contemporary graduates' career values. The REFLEX project, a study of approximately 70,000 from 16 countries, categorised graduates' career (or work) values as extrinsic and intrinsic (Allen et al. 2007). Extrinsic values are related to survival and intrinsic to satisfying higher order needs (Maslow 1954) through work which is varied, autonomous, challenging and provides meaning to the individual. Drawing on Teichler (2007), REFLEX identified three types of career orientations: one based solely on survival/extrinsic values (career), another entirely on intrinsic (professional/innovative) and a final one combining both security and self-expression (social/family). In alignment with Farag and Allen (2003), intrinsic factors were broadly more important than extrinsic factors in determining job satisfaction. Overall, these values can shape graduates' perceived career outcomes and approaches to career management.

Intrinsic factors are increasingly featured in students’ and graduates’ career decision-making and behaviour, considerable value being placed on meaningful work (Allan, Owens, and Duffy 
2017). Relating this to the broader labour market, employees are concerned with sustainability, societal impact, transparent executive remuneration, fair and competitive compensation, opportunities for promotion, clear leadership, workplace lifestyle and flexible working arrangements (Mercer 2017). Indeed, Allan and colleagues reported that undergraduates consider sourcing meaningful work as an important goal of career counselling. In their annual graduate survey, Deloitte (2018) also evidenced the importance of both intrinsic and extrinsic values with graduates' 'wish list' including pay, positive workplace culture, flexibility, and opportunities for learning. Increased extrinsic motivation for attending college is reported among Millennials students, as well a propensity for higher extrinsic-related life goals and preferred job type (see Twenge and Donnelly 2016). The following hypothesis is thus presented:

$\mathrm{H}_{1}$ : Intrinsic and extrinsic factors underpin students’ career values.

Allen et al. (2007) found that females scored more highly on the professional/innovative and social/family career orientations. Several studies have found males demonstrate stronger extrinsic career values than females (Johnson 2002; Schwartz and Rubel 2005). For example Inceoglu et al. (2008) reported that females are less driven by status and income and more by freedom, variety and community in their work. Some studies have evidenced an age effect in the adoption of intrinsic and extrinsic values, with intrinsic values more apparent among older workers (Segers et al. 2008; van der Velde, Feji, and van Emmerick 1998) Hansen and Leuty (2012), however, asserted that effects are complicated by generational differences and Jackson and Wilton (2016) found age did not determine career values.

It is possible that career values may vary with socio-economic status. Duffy and Sedlacek (2007a), for example, found that students whose parents were in middle income brackets, as 
opposed to high or low, were more likely to indicate intrinsic values. The affiliation among high or low income-earning families with extrinsic values may be attributed to a social reproduction with income effects being felt more in the extreme income bands and influencing their own motivation and goals more acutely. One might also expect a greater prevalence of intrinsic values among students enrolled in certain disciplines, such as Education or Health and Social Care, and by stage of study. Given the apparent limited empirical evaluation and mixed effects reported for influences on graduates' career values, the following broad research question is posed, rather than a series of directional hypotheses.

$\mathrm{RQ}_{1}$ : Adoption of extrinsic and intrinsic career values will vary with study and individual characteristics.

\section{Career proactivity}

Career proactivity relates to an individual's ability to purposively develop goals and strategies in relation to the planning and execution of career-related outcomes and is seen as a significant component of wider career competences (Akkermans and Timms 2017). It embodies behaviours which enable individuals to take greater ownership over the direction of their career outcomes and navigate more successfully through a range of career challenges and risks. As a behavioural construct, proactivity is likely to influence an individual's level of career adaptability and resourcefulness, including propensity to engage in self-starting behaviours and craft out new opportunities (ibid). It is broadly considered to be malleable through, for example, curriculum and pedagogy in the HE context (see Tymon and Batistic 2016). Career proactivity is a sought after element of student employability (Fugate et al., 2004), important for career self-management (Tomlinson 2012) and for securing and sustaining employment (Fuller et al. 2010; Tomlinson 2007). Studies on career proactivity are often employee-based, exploring behaviours such as networking, skill development and career planning (Taber and Blankemeyer 2015), and focused on the relationship with career success and outcomes (for example, Smale 
et al. 2018; van Veldhoven and Dorensbosch 2008). Such research has demonstrated a strength of association between proactivity and expanded job opportunity development through the application of a range of effective career management endeavours.

Whilst proactivity can be broadly defined in terms of career competencies that encompass social and behavioural properties pertaining to an individuals’ capacity to manage their career, it can also be conceived as a variant of a future employees' career values. Accordingly, it may influence, or indeed be influenced by, some of the different goals and orientations discussed earlier. Abessolo, Rossier, and Hirschi (2017) found that certain intrinsic work values which underpin contemporary working, such as autonomy and achievement, were positively associated with the protean career orientation which indicates higher propensity towards selfmanaged career pursuits. As Hall and Moss (1998) posit, the contract for employment is no longer with the organisation but with oneself and one's work, requiring proactivity and selfmanagement. Koestner et al. (2002) meta-analysis found that intrinsically-driven goals, compared with extrinsically-motivated ones, are more likely to lead to proactivity and attainment.

$\mathrm{H}_{2}$ : Career proactivity will be positively associated with career values.

Amid highly competitive graduate labour markets, career proactivity includes students constructing a personal narrative on their capabilities, achievements and strengths which they may articulate using, for example, CVs, ePortfolios and social media platforms such as LinkedIn. In this sense, students are the enterprising subject of HE institutions in a neo-liberalist era in which some groups may engage better than others. Given the apparent lack of empirical evaluation of career proactivity among different student groups, the led to the following broad research question. 
$\mathrm{RQ}_{2}$ : Do individual and study characteristics determine career proactivity among HE students?

\section{Method}

\section{Participants}

Undergraduate and postgraduate students $(N=433)$ from two universities participated in the study. The broadly similar HE sector and gradute labour market environments prompted an international research design with data gathered from the UK and Australia. The first, smaller institution was based in Western Australia $(N=307)$ and the second was a research intensive institution, based in England and part of the Russell group ( $N=126)$. These countries were chosen given similarities in their HE systems, labour market characteristics and prioritisation of the employability agenda. Further, Australia's intense focus on objective employment outcomes as a means of measuring student and institutional success and the UK's recent introduction of broader measures to gauge student success provided a rich context with respect to gauging HE students' career values. A summary of participant characteristics is presented in Table 1 . The sample broadly reflects each institutions' population characteristics with the majority aged under 30 years, approximately one-quarter are international students and there is a greater proportion of female students. The sample was drawn from a broad range of disciplines, with notably more from Social Sciences, and students were at various stages of study. Institutional differences include relatively more females, international, postgraduate and younger students in the UK university.

[Table 1 near here]

\section{Procedures}

Participants were invited to complete an online survey in two different ways. In Australia, the researcher circulated the survey link and project details to unit coordinators from a diverse range of disciplines. Coordinators distributed information on the survey via an announcement email 
on the university's learning management system. In the UK university, the survey link and information was posted on career forum websites and social media platforms, as well as undergraduate and postgraduate intranet sites often used to recruit students for research projects. Separate ethics approval was granted in each university and data were collected between March and August 2018.

\section{Measures}

Students were asked to first provide detail on their study and individual characteristics, as per Table 1. The operationalised proxy for socio-economic status was parental occupation, given the difficulties in gathering accurate detail on students' residential postcode and their propensity for temporary accommodation. Data were gathered for both parents (see Table 1), classified using occupation codes employed in Australia (Australian Bureau of Statistics, 2013). A binomial variable was then created for the highest classification of their parents occupation (Manager/Professional or not). For stage of study, first year undergraduates were classed as 'early', second years as 'mid' and those in year three or beyond as 'late' stage undergraduates. First year postgraduate students were classed as ‘early' and those in their second year or beyond as 'late’ stage postgraduates.

Eight items were used to explore students' intrinsic and extrinsic career values, similar to those used in the Reflex project (Allen et al. 2007) and also informed by Deloitte (2016) and Sortheix et al. (2013). Three items were used to capture students’ career proactivity, broadly informed by literature on career self-management. Both the career values and proactivity scales used a five-point Likert agreement with 'neither agree nor disagree’ used as the middle point. Students were also asked to provide textual responses to 'what are the three main things which have most shaped your decision on which career to enter'. Three text boxes were provided for the open responses which were not mandatory. 


\section{Analysis}

First, the Harman's single factor test (Podsakoff, Mackenzie, and Podsakoff 2003) was conducted to gauge common method variance given the study's sole use of self-report data. A three-factor solution emerged, accounting for $57.867 \%$ of variance, and the one-factor solution accounted for only $30.712 \%$ of the variance. Common method bias was therefore not considered a concern. Normality was examined for variables and measures of kurtosis and skewness were within 'normal limits', less than 7 and 2 respectively (Curran, West, and Finch 1996). To address the first research question, Principal Components Analysis (PCA) was conducted to determine the underlying dimensions of career values. Factor solutions were interpreted and the number of factors determined using eigenvalues, scree plots and factor loadings. Variations in career values were analysed using multiple linear regression on the generated factor scores for both intrinsic and extrinsic career values.

Thematic analysis was then conducted of the open responses (up to three per case) for the factors which shaped their decision on the career they wished to enter. To enhance trustworthiness (Merriam 1995), data were initially analysed by an external, trained researcher and then the analysis was repeated by one of the research investigators. Once the themes were identified and responses classified, a duplication check confirmed that none of the individuals' three responses featured in the same sub-theme. Further, each response was classified without difficulty into a singular theme or sub-theme. Areas of difference were highlighted and the data revisited to achieve consensus. To address the second research objective, a multiple linear regression was conducted to examine determinants of proactivity. Inter-item consistency of scales was computed using Cronbach alpha for both career values and career proactivity. 
Quantitative data analysis was conducted using SPSS 24.0 and the thematic analysis of the open response questions using Excel.

\section{Results}

\section{Career values}

PCA produced a two factor solution for career values with the pattern matrix presented in Table 2. The first reflected extrinsic factors, explaining $28.950 \%$ of the total variance and with an eigenvalue of 2.316, and the second was associated with intrinsic factors. This had an eigenvalue of 1.829 and explained $22.861 \%$, with $51.811 \%$ of the total variance explained. Kaiser-Meyer-Olkin (KMO) measure of sampling adequacy was .70, above the recommended value of 0.6 (Pallant 2001, 182), and Bartlett's test of sphericity was significant $(p<.001)$. Cronbach alpha was computed to assess inter-item consistency of scales and was .68, approaching the commonly used threshold of .7 and exceeding the acceptable level of 0.6 (Nunnally and Bernstein 1994). Factor loadings exceeded 0.5 (Hair et al. 2010). Two clear factors emerged, the first aligning with extrinsic and the second intrinsic elements. Results therefore support hypothesis one that intrinsic and extrinsic factors underpin students' career values.

[Table 2 near here]

Factor scores were computed for each observation on each factor and were used for the linear regression analyses (see DiStefano et al. 2009). Base variables for gender, residency, stage of study and discipline are denoted by (0) in Table 1. The highest parental classification not being a manager/professional was set to 0 , those being a manager/professional coded to 1 . The UKbased institution was set as the base variable. Bivariate correlations were examined among the continuous predictor variables with none exceeding 0.6 , considered problematic for Type II 
errors (Grewal, Cote, and Baumgartner 2004). Multicollinearity was not present given the absence of inflated standard errors and the Variance Inflation Factor (VIF) being within the accepted threshold of 2 (George and Mallery 2010). Further, first order linear auto-correlation was not evident as the Durbin-Watson test statistic of 1.902 was close to the critical value of two (Norusis 2008).

The results of the linear regression on extrinsic values are presented in Table 3. Regression coefficients indicate the expected change in extrinsic values for each independent variable, holding other variables in the model constant. The model was significant, $F(12,383)=3.112$, $p<.000$. The standardised coefficients indicated a significant result for age with older students scoring lower on extrinsic values. Further, international students were associated with higher ratings for extrinsic values than their domestic counterparts. Those in the early stages of their postgraduate studies achieved higher ratings in extrinsic values than those in the initial stages of their undergraduate degree.

[Table 3 near here]

The linear regression on intrinsic values is presented in Table 4. The model was significant, $\mathrm{F}(12,383)=3.163, p<.000$ and there were no concerns for multicollinearity or first order linear auto-correlation $(d=2.080)$. Results indicated that students from the Australian university scored higher in intrinsic values, as did Health and Social Care students compared with those from the STEM disciplines. Although the standardised regression coefficient only approached significance, there was some evidence that those students who have at least one parent working in a managerial or professional role achieved lower ratings than students who did not.

[Table 4 near here] 


\section{Career proactivity}

First, descriptive techniques were used to compute the mean scores for the three items measuring proactivity. These were $4.06(S D=.816)$ for 'I am keen to get on the career ladder'; $4.36(S D=.723)$ for 'having a career is important to me' and $4.22(S D=.802)$ for 'I think strongly about my future career'. A composite mean for the three items was computed. The mean was 4.21 with an associated standard deviation of .665. Results indicated that proactivity was certainly evident in the student sample. Factor analysis showed the three items loading cleanly onto one factor, explaining $72.707 \%$ of the total variance and with scores ranging from .833 to .880. The reported Cronbach alpha was .81 .

Linear regression was conducted on the factor scores for career proactivity, see Table 5. Again, multicollinearity and first order linear auto-correlation were not evident $(d=1.883)$. The model was significant, $\mathrm{F}(14,375)=10.132, p<.000$, and the adjusted $\mathrm{R}^{2}$ of .247 indicates reasonable model fit. Interestingly, results indicated a negative significant age effect on career proactivity, suggesting that stronger career proactivity is associated with younger HE students. No other individual or study characteristics reported significant results. The lack of effect for stage of study is interesting as one might expect students in their later years to be more motivated in their career behaviour. There was a strong positive association between both intrinsic and extrinsic values with career proactivity, supporting hypothesis two. This suggests that students who have stronger career values - whether focused on extrinsic reward or motivated by intrinsic values - are more likely to demonstrate proactive career attitudes and behaviours.

[Table 5 near here]

\section{Factors underpinning decision-making.}


Twelve overarching themes were identified, some containing a number of sub-themes. The themes and sub-themes are summarised in Table 6 with a frequency count for each category. [Table 6 near here]

\section{Extrinsic factors}

Of the 197 comments noting extrinsic factors as influencing their decision on which career to enter, almost one-half related to job prospects and opportunities. There was a widespread preference for their targeted profession or industry offering superior opportunities for career progression and promotion while others noted the weak economic climate and soft labour market influencing their career decision-making. For one-third of those emphasising extrinsic factors, income was a determining factor. A desire for job security and high status was also apparent, although to a lesser extent.

\section{Intrinsic factors}

Intrinsic factors were the most commonly cited theme with 287 comments stating they were important to students when deciding which career to enter. Ninety-two of the students were driven by a sense of purpose and the meaning they derived from their targeted or chosen career. There was significant evidence within these responses of students wishing to make a societal contribution and 'give back' in some meaningful way. The same number of students stated they pursued their given career due to a sense of calling or long-felt passion. Students used words such as 'lifelong fascination', 'an interest since I was a teenager', and 'I've always enjoyed' to describe their 'calling'. To a lesser extent, students chose a career which aligned with their personal values and beliefs. Fulfilment was also cited as a key factor in career-decision making, several of these 30 students noted the importance of job satisfaction, one stating 'where I think I would be the happiest and enjoy the work'. Feeling challenged and opportunity to be creative 
was important for 22 students when choosing a career and, finally, work-life balance featured in 16 student responses with some of these focused on balancing their career with childcare duties.

\section{Work role and environment}

There was a fairly equal distribution of responses across the seven sub-themes in this category, responses ranging from six to 14. Respondents commented on appreciating social and collaborative working environments, as well as valuing careers that offered flexibility, high levels of responsibility and variety. Opportunity for travel and being in a convenient location was important for some. A small number noted the importance of employer credibility particularly around reputation and corporate social responsibility - while favourable working conditions were also appealing to some. Interestingly, there was only one response within this 'general environment' sub-theme that referred to corporate culture.

\section{Other factors}

Many students stated in very direct terms that their career choice was determined by interest for operating in a particular field or industry. Eighteen students stated their decision was guided by their career goals. Most responses did not clarify how they established their goals and only two stated they were long-standing aspirations. Learning and development emerged as an important factor for students deciding which career to enter with responses focused on personal growth, expanding and deepening knowledge, a passion for learning and continuing their journey of professional development.

Fifty six comments related to the individuals' own strengths and capabilities guiding their career decision-making. Students mentioned the importance of person-role fit, commenting 'it 
is what I am good at' or 'I am a people person'. Some noted their strong academic skills, confidence and technical expertise but generally responses did not yield specific observations on the actual skills they felt they excelled at and which were needed for their chosen career. Several commented on the value of their prior work or work experience for guiding decisionmaking. A small number stated that their, for example, 'failure with past opportunities', helped to clarify what they did not want to do in the future. Forty seven of the comments related to their education and acquired qualifications guiding career choices. A high proportion noted the value of degree studies while others mentioned high school and professional qualifications. For all but two, education was considered useful. For the remaining students, their failure in previous education had forced them to pursue their (different) chosen pathway.

Networks played an important role in students deciding which career to enter with 77 comments relating to how this influenced career decision-making. More related to informal networks family, friends and fellow students - rather than professional networks, such as colleagues in current or previous roles, mentors, or professionals as role models. One student stated, for example, 'meeting professionals in the field who have been inspiring' and another, 'watching the teachers of my son solidified my dream to become a teacher'. The use of social media was highlighted, albeit in only a small number of responses. Some students acknowledged the influence of others but did not clarify whom.

Life experience featured in 27 of the comments. Many referred to specific events - including health and trauma - that occurred to them or close others while some spoke broadly of their experiences as a consumer or citizen. The 'other' grouping consisted of five sub-themes. First a small number were guided by their own gender or age. Second, some stated the career they entered occurred through natural progression or simply a gut feeling. Some attributed their 
career decision-making to research on available opportunities and pathways. Others felt their decisions were prompted by the need for a career change, expressing dissatisfaction with their current or previous choices.

\section{Discussion}

\section{Theoretical contribution}

Findings emphasise the importance of both intrinsic and extrinsic values in HE students' career decision-making and their role in determining proactivity in career management behaviour. Of the extrinsic values, income and job prospects were more important than status and job security. According to Sortheix et al. (2015), values emphasising security may 'hold back young individuals from adapting flexibly to the labor market' (164), decreasing their chances of attaining employment. For intrinsic comments resonated with Praskova, Creed and Hood (2015) notion of career calling in young adults, defined as 'mostly self-set, salient, higher-order, career goal, which generates meaning and purpose for the individual (and the community), and which has the potential to be strengthened (or weakened) by engaging in goal-directed, careerpreparatory actions and adaptive processes aimed at meeting this goal' (3). To a lesser extent, students are motivated to enter a certain career based on the nature of the job role and work environment - rather than just a long-term interest in that particular field.

Findings contravene the traditional notion that males are more extrinsically-driven (Duffy and Sedlacek 2007a; Sortheix et al. 2013). This may indicate an easing of traditional societal expectations that males will 'provide' for the family, creating associated pressures with earnings, job status for class assignment and job security, and that females' career decisionmaking are still influenced by competing role priorities (see Battle and Wigfield 2003). The absence of gender differences for intrinsic values suggests that autonomy, challenge, work-life 
balance and societal contribution are equally important to both males and females. This contrasts with Sortheix et al. (2015) who found a significant negative association for males with intrinsic values and no gender association for reward values.

Students from the more vocationally-oriented (as opposed to research-intensive) Australian university placed greater emphasis on intrinsic values, along with those who did not have parents working in a professional or managerial role. Given the institution's high proportion of students that are first-in-family to attend university, one might conclude that students who are less professionally-connected could be more focused on pursuing careers that offer challenge and opportunity to make a meaningful contribution. That Health and Social Care students are more intrinsically-motivated than those from the 'harder', STEM disciplines is unsurprising. The graduate employment outcomes in these disciplines are traditionally among the weakest (Social Research Centre, 2018) yet these students still choose to enrol, clearly seeking satisfaction in other ways.

That older students assigned lower ratings to extrinsic values is interesting, particularly as job security and earnings are featured items and one might expect greater emphasis on financial stability among those more likely to be home owners and supporting children. Cennamo and Gardener (2008) suggested that a heightened focus on achievement and status may simply reflect the enthusiasm of early career stages while Twenge et al.’s (2012) evidenced an ongoing, rising trend in extrinsic values across more recent generations. Twenge and colleagues also found that Millennials' desire for greater income and status is coupled with a desire to work less hours, providing some support for widely publicised concern for the inflated expectations and sense of entitlement associated with Millennials (Chatrakul Na Ayudhya, and Smithson 2016). As Twenge and colleagues note, this has implications for job design, person-organisation 
fit and retention, as well as recruitment techniques for attracting younger graduates. Higher extrinsic values among early-stage postgraduates may reflect their motivation to invest in further study, such as greater award, opportunities for promotion and higher status. Given their background is largely unknown, it is difficult to infer the cause of stronger extrinsic values among international students yet it highlights an area for further exploration.

Findings indicated that students whose career decision-making was values-driven were more likely to demonstrate proactive career management behaviours. This was, as predicted, attributed to those focused on promotion or income-focused reward more likely to foster active career self-management and job seeking (van Hoof, Wanberg, and van Hoye 2013). This is particularly so in the uncertain economic climates and soft graduate labour markets prevalent in both the UK and Australia. Similarly, the desire to secure work that provides enjoyment and a sense of purpose will, according to Dietrich and colleagues (2013), motivate individuals to pursue their work goals in an ongoing fashion. Duffy and Sedlacek (2007b) found that a career calling among college students was positively correlated with career decidedness, choice comfort and self-clarity.

\section{Practical contribution}

In terms of career interventions and counselling, universities should also account for the importance of intrinsic and extrinsic values and how different student groups may favour each. Despite performance metrics for universities increasingly focusing on extrinsic graduate outcomes (Jackson and Bridgstock 2018), findings emphasise the importance of intrinsic measures, such as the items for anxiety and well-being in the UK's new national Graduate Outcomes Survey (Higher Education Statistics Agency 2018). Embedding strategies which encourage students to 'tease out' and develop an understanding of their values, interests and 
what motivates them from the early stages of study will assist them in researching and pursuing aligned career pathways. Career counselling which assists students with heightening student understanding of their passion and calling aids career self-management (Duffy and Sedlacek 2007b) and improves career outcomes (Praskova et al. 2015).

Increasingly, universities are introducing interventions such as portfolios and reflective tools which enable students to not only record their achievements and activities but also to look within and understand their values and what is important to them. It is important to be able to articulate these to graduate employers who place considerable emphasis on personal and cultural fit during recruitment processes (Hinchliffe and Jolly 2011). An alternative approach, perhaps for certain international student groups who may be more versed with rote learning than reflection and the development of self-awareness, would be researching roles and industries against which they can gauge their own suitability and interest. Other tools to help students understand, benchmark and articulate their strengths and capabilities beyond academic knowledge are skill audits, psychometric testing and assessment centres.

Work experience is important for career-decision making and the formation of career attitudes (Trolian, Jach and Snyder 2018) and facilitating this through work integrated learning (WIL) programmes, volunteering and connecting students with paid work opportunities is critical. Findings affirm the importance of encouraging students to gain life experience through cocurricular and extra-curricular activities - such as global internships, service learning, community, club and sports-based activities - to aid career decision-making. Further, facilitating networking via formal peer or industry mentoring programmes, and WIL is also important, whether embedded or as part of centralised, co-curriculum offerings. The malleable nature of career proactive behaviours emphasises the importance of counsellors and educators 
engaging with students on the importance and benefits of being responsible for and proactive with their career management, particularly those less likely to, such as mature students. The pedagogy of student-centred learning is considered important for fostering proactivity (van der Merwe, McChlery and Visser 2014), as well as combining both practical and cognitive aspects into activities and assessments and focusing on problem solving, change management and critical thinking (see Tymon and Batistic 2016).

For graduate employers, careful consideration should be given to the content and promotion of graduate programmes and entry-level roles as students do pursue pathways based on role design and work environment. Variations in values and motivations by age, however, suggest employers may wish to consider their recruitment strategies and adopt a more nuanced approach rather than one-size-fits-all. Appealing salaries, clear promotion pathways, opportunities for learning and development, and good job prospects appear important for attracting talent. Clarifying precisely what entry-level and programme roles entail may help students to more accurately assess alignment to their own values and whether they will provide that highly desired sense of purpose and level of enjoyment.

\section{Conclusion}

The study builds on previous empirical work on student career values (Allen et al. 2017), adding to the dearth of research in this area (Duffy and Sedlacek 2007a). The study findings enhance our understanding of the main career values that shape students' career goals and planning, as well as the influence of individual characteristics. An enhanced knowledge base on the career motivations among different groups of students provides guidance for career counsellors, as well as inform graduate employers’ recruitment processes and strategies for attracting and retaining talent. The association between career values and career proactivity highlights the 
need to implement strategies within the curriculum, or through career service provision, to help students understand and clarify what is important to them and why and identify groups that may be less prone to seeking assistance and engaging in career-related learning. Moreover, this can help students' better align their profiles and emerging career identities more strongly towards targeted jobs and organisation, which may enable a stronger fit between the graduate and a given workplace.

The study has limitations. First, data were self-report which could raises concern with bias yet the focus on individual values and perceived importance of careers rendered it most appropriate for the study. Common method variance was examined yet the study draws on cross-sectional data, albeit from two different geographical sources. The proxy variable for socio-economic status is somewhat elementary. The research attracted a reasonable sample and gathered data from students across different disciplines and stages of study in two reasonably similar contexts, allowing for results to be generalised with caution. A possible direction for future research would be utilising an instrument for gauging career values which collapses intrinsic and extrinsic values into more detailed categories, such as those employed by Sortheix et al. (2015). A longitudinal analysis of how career values evolve as students' transition to the workforce and pursue different career pathways, including variations for different groups of individuals, would provide a valuable contribution to research in this area. 


\section{References}

Abessolo, M., J. Rossier, and A. Hirschi. 2017. "Basic values, career orientations, and career anchors: Empirical investigation of relationships”. Frontiers in psychology 8: 1556.

Akkermans, J, and M. Tims. 2017. “Crafting your career: how career competencies relate to career success via job crafting”. Applied Psychology 66 (1): 168-195.

Allan, B., R. Owens, and R. Duffy. 2017. “Generation me or meaning? Exploring meaningful work in college students and career counsellors”. Journal of Career Development 44 (6): 502515.

Allen, J., C. Arnesen, J. Calmand, M. Frontini, J. Paul, M. Rostan, and R. Velden. 2007. The flexible professional in the knowledge society: General results of the REFLEX project. Maastricht, Netherlands: Maastricht University.

Australian Bureau of Statistics. 2013. Australian and New Zealand standard classification of occupations. Canberra, Australia: ABS.

Battle, A., and A. Wigfield. 2003. “College women’s value orientations toward family, career, and graduate school”. Journal of Vocational Behavior 62 (1): 56-75.

Bravo, J., S. Seibert, M. Kraimer, S. Wayne, and R. Liden. 2017. “Measuring career orientations in the era of the boundaryless career”. Journal of Career Assessment 25 (3): 502525.

Bridgstock, R. 2011. "Skills for creative industries graduate success”. Education and Training 53 (1): 9-26.

Briscoe, J., and Hall, D. 2006. “The interplay of boundaryless and protean careers:

Combinations and implications”. Journal of Vocational Behavior 69 (1): 4-18.

Cennamo, L., and D. Gardner. 2008. "Generational differences in work values, outcomes and person-organization values fit”. Journal of Managerial Psychology 23 (8): 891-906. 
Chatrakul Na Ayudhya, U., and J. Smithson. 2016. "Entitled or misunderstood? Towards the repositioning of the sense of entitlement concept in the generational difference debate”. Community, Work \& Family 19 (2): 213-226.

Cochran, L. 1983. “Implicit versus explicit importance of career values in making a career decision”. Journal of Counseling Psychology 30 (2): 188-193.

Curran, P., S. West, and J. Finch. 1996. "The robustness of test statistics to non-normality and specification error in confirmatory factor analysis”. Psychological Methods 1 (1): 16-29. Deloitte. 2016. The 2016 Deloitte millennial survey: Winning over the next generation of leaders. London, UK: Deloitte.

Deloitte. 2018. The 2018 Deloitte millennial survey: London, UK: Deloitte.

Dietrich, J., S. Shulman, and J. Nurmi. 2013. “Goal pursuit in young adulthood: The role of personality and motivation in goal appraisal trajectories across 6 years”. Journal of Research in Personality 47 (6): 728-737.

DiStefano, C., M. Zhu, and D. Mindrila. 2009. “Understanding and using factor scores: Considerations for the applied researcher”. Practical Assessment, Research \& Evaluation 14 (20): 1-11.

Duffy, R., and W. Sedlacek. 2007a. “The work values of first-year college students: Exploring group differences”. The Career Development Quarterly 55 (4): 359-364.

Duffy, R., and W. Sedlacek. 2007b. “The presence of and search for a calling: Connections to career development”. Journal of Vocational Behavior 70 (3): 590-601.

Farag, S., and J. Allen. 2003. “Japanese and Dutch graduates’ work orientations and job satisfaction”. In: Competencies, Higher Education and Career in Japan and the Netherlands, 191-210. Dordrecht, Netherlands: Springer.

Fugate, M., A. Kinicki, and B. Ashforth. 2004. "Employability: A psycho-social construct, its dimensions, and applications”. Journal of Vocational Behavior 65 (1): 14-38. 
Fuller, Jr. J., K. Kester, and S. Cox. 2010. “Proactive personality and job performance: Exploring job autonomy as a moderator”. Journal of Managerial Issues 22 (1): 35-51. George, D., and M. Mallery. 2010. SPSS for Windows step by sStep: A simple guide and reference, 17.0 update. Boston, USA: Pearson.

Grewal, R., J. Cote, and H. Baumgartner. 2004. "Multicollinearity and measurement error in structural equation models: Implications for theory testing”. Marketing Science 23 (4): 51929.

Hair, J., W. Black, B. Babin, and R. Anderson. 2010. Multivariate data analysis. Upper Saddle River, NY: Prentice-Hall.

Hall, D., and J. Moss, J. 1998. “The new protean career contract: Helping organizations and employees adapt”. Organizational dynamics 26(3): 22-37.

Hansen, J., and Leuty, M. 2012. “Work values across generations”. Journal of Career Assessment 20 (1): 34-52.

Heslin, J. 2005. “Conceptualising and evaluating career success”. Journal of Organizational Behaviour 26 (2): 113-136.

Higher Education Statistics Agency. 2017. New DELHE: The future of graduate outcomes data. Cheltenham, UK: HESA.

Hinchliffe, G., and A. Jolly. 2011. “Graduate identity and employability”. British Educational Research Journal 37 (4): 563-584.

Inceoglu, I., J. Segers, D. Bartram, and D. Vloeberghs. 2008. “Age differences in work motivation”. Paper presented at the 23rd Annual Conference of the Society for Industrial and Organizational Psychology, San Francisco.

Jackson, D., and R. Bridgstock. 2018. "Evidencing student success and graduate employability in the contemporary world-of-work: renewing our thinking”. Higher Education Research and Development 37 (5): 984-998. 
Jackson, D., and R. Bridgstock. 2019. “Evidencing student success and career outcomes among Business and Creative Industries graduates". Journal of Higher Education Policy and Management 41 (5): 451-467.

Jackson, D., and N. Wilton. 2016. “Developing career management competencies among undergraduates and the role of work-integrated learning”. Teaching in Higher Education 21 (3): 266-286.

Johnson, M. 2002.”Social origins, adolescent experiences, and work value trajectories during the transition to adulthood”. Social Forces 80 (4): 1307-1341.

Johnson, M., and M. Monserud, M. 2010. “Judgments about work and the features of young adults' jobs”. Work and Occupations 37 (2): 194-224.

Johnson, M., and J. Mortimer. 2011. “Origins and outcomes of judgments about work”. Social Forces 89 (4): 1239-1260.

Judge, T., and R. Bretz. 1992. “Effects of work values on job choice decisions”. Journal of Applied Psychology 77 (3): 261-271.

Koestner, R., N. Lekes, T. Powers, and E. Chicoine. 2002. “Attaining personal goals: Selfconcordance plus implementation intentions equals success”. Journal of Personality and Social Psychology 83 (1): 231-244.

Maslow, A. 1954. Motivation and personality. New York, USA: Harper \& Row. Mercer. 2017. Talent trends - empowerment in a disruptive world. New York, USA: Mercer. Merriam, S. 1995. "What can you tell from an $\mathrm{N}$ of 1 ? Issues of validity and reliability in qualitative research”. PAACE Journal of Lifelong Learning 4: 50-60.

Ng, T., L. Eby, K. Sorensen, and D. Feldman. 2005. "Predictors of objective and subjective career success. A meta-analysis”. Personnel Psychology 58 (2): 367-408..

Nunnally, J., and I. Berstein. 1994. Psychometric Theory. New York, US: McGraw-Hill. 
Norusis, M. 2008. SPSS statistics 17.0 statistical procedures companion. Upper Saddle River, NJ: Prentice-Hall.

Pallant, J. 2001. SPSS Survival Guide: A step by step guide to data analysis using SPSS. Melbourne, Australia: Allen \& Unwin.

Podsakoff, P., S. MacKenzie, J. Lee, and N. Podsakoff. 2003. “Common method biases in behavioral research: A critical review of the literature and recommended remedies”. Journal of Applied Psychology 88 (5): 879-903.

Praskova, A., P. Creed, and M. Hood. 2015. “The development and initial validation of a career calling scale for emerging adults”. Journal of Career Assessment 23 (1): 91-106. Quigley, N., and W. Tymon. 2006. “Toward an integrated model of intrinsic motivation and career self-management”. Career Development International 11 (6): 522-543.

Rojewski, J., C. Pisarik, C, and H. Han. 2017. “Classifications of college students’ protean and boundaryless orientation to work”. International Journal for Educational and Vocational Guidance 17(3): 329-346.

Schwartz, S., and T. Rubel. 2005. "Sex differences in value priorities: Cross-cultural and multimethod studies”. Journal of Personality and Social Psychology 89 (6): 1010-1028. Segers, J., I. Inceoglu, D. Vloeberghs, D. Bartram, and E. Henderickx. 2008. "Protean and boundaryless careers: A study on potential motivators”. Journal of Vocational Behavior, 73 (2): 212-230.

Seibert, S., M. Kraimer, and J. Crant. 2001. “What do proactive people do? A longitudinal model linking proactive personality and career success”. Personnel psychology 54 (4): 845874.

Smale, A., S. Bagdadli, R. Cotton, S. Dello Russo, M. Dickmann, A. Dysvik, and P. Rozo. 2018. "Proactive career behaviors and subjective career success: The moderating role of national culture”. Journal of Organizational Behavior 40 (1): 105-122. 
Social Research Centre. 2018. 2018 Graduate Outcomes Survey - national report.

Melbourne, VIC: SRC.

Sortheix, F., J. Dietrich, A. Chow, and K. Salmela-Aro. 2013. "The role of career values for work engagement during the transition to working life”. Journal of Vocational Behavior 83 (3): $466-475$.

Sortheix, F., A. Chow, and K. Salmela-Aro. 2015. "Work values and the transition to work life: A longitudinal study”. Journal of Vocational Behavior 89: 162-171.

Taber, B., and M. Blankemeyer. 2015. "Future work self and career adaptability in the prediction of proactive career behaviors”. Journal of Vocational Behavior 86: 20-27. Teichler, U. 2007. Careers of university graduates: Views and experiences in comparative perspectives (Vol. 17). Dordrecht, Netherlands: Springer.

Tight, M. 2019. “Mass higher education and massification”. Higher Education Policy, 32 (1): 93-108.

Tomlinson, M. 2007. “Graduate employability and student attitudes and orientations to the labour market”. Journal of Education and Work 20(4): 285-304.

Tomlinson, M. 2012. “Graduate employability: A review of conceptual and empirical Themes”. Higher Education Policy 25 (4): 407-431.

Trolian, T., E. Jach, and K. Snyder. 2018. “Connecting college and work: examining the relationship between students' college employment experiences and their professional and career attitudes”. Journal of Education and Work 31 (4): 366-380.

Twenge, J., and K. Donnelly, K. 2016. “Generational differences in American students’ reasons for going to college, 1971-2014: The rise of extrinsic motives”. The Journal of social psychology 156 (6): 620-629. 
Twenge, J., W. Campbell, and E. Freeman. 2012. “Generational differences in young adults' life goals, concern for others, and civic orientation, 1966-2009”. Journal of personality and social psychology 102 (5): 1045.

Tymon, A., and S. Batistic. 2016. "Improved academic performance and enhanced employability? The potential double benefit of proactivity for business graduates”. Teaching in Higher Education 21 (8): 915-932.

van der Merwe, N., S. McChlery, and S. Visser. 2014. "Balancing academic and professional pedagogies: A comparative study of two Accounting departments in South Africa and the UK”. Teaching in Higher Education 19 (3): 276-288.

Van Hooft, E., C. Wanberg, and G. Van Hoye. 2013. “Moving beyond job search quantity: Towards a conceptualization and self-regulatory framework of job search quality”. Organizational Psychology Review 3 (1): 3-40.

van der Velde, M., J. Feji, and H. van Emmerick. 1998. “Change in work values and norms among Dutch young adults: Aging or societal trends?” International Journal of Behavioral Development 22 (1): 55-76.

van Veldhoven, M., and L. Dorenbosch. 2008. “Age, proactivity and career development”. Career Development International 13 (2): 112-131. 
Table 1 Summary of participant characteristics

\begin{tabular}{|c|c|c|c|c|c|c|c|}
\hline \multirow{2}{*}{ Variable } & \multirow[b]{2}{*}{ Sub-groups } & \multicolumn{2}{|c|}{$\begin{array}{l}\text { Australian } \\
\text { Institution }\end{array}$} & \multicolumn{2}{|c|}{$\begin{array}{c}\text { UK } \\
\text { Institution }\end{array}$} & \multicolumn{2}{|c|}{ Total } \\
\hline & & $\mathbf{N}$ & $\underset{\%}{\text { Valid }}$ & $\mathbf{N}$ & $\begin{array}{l}\text { Valid } \\
\%\end{array}$ & $\mathbf{N}$ & $\begin{array}{l}\text { Valid } \\
\%\end{array}$ \\
\hline \multirow[t]{2}{*}{ Gender } & Male(0) & 111 & 36.2 & 31 & 24.6 & 142 & 32.8 \\
\hline & Female & 196 & 63.8 & 95 & 75.4 & 291 & 67.2 \\
\hline \multirow{4}{*}{$\begin{array}{l}\text { Age group } \\
\text { (years) }\end{array}$} & $0-20$ & 62 & 20.2 & 26 & 20.6 & 88 & 20.3 \\
\hline & $21-30$ & 149 & 48.5 & 86 & 68.3 & 235 & 54.3 \\
\hline & $31-40$ & 60 & 19.5 & 8 & 6.3 & 68 & 15.7 \\
\hline & $41+$ & 36 & 11.7 & 6 & 4.8 & 42 & 9.7 \\
\hline \multirow[t]{2}{*}{ Residency } & Domestic(0) & 247 & 80.5 & 90 & 71.4 & 337 & 77.8 \\
\hline & International & 60 & 19.5 & 36 & 28.6 & 96 & 22.2 \\
\hline \multirow[t]{5}{*}{ Stage of study } & UG Early(0) & 78 & 25.7 & 17 & 13.5 & 95 & 22.1 \\
\hline & UG Mid & 53 & 17.5 & 19 & 15.1 & 72 & 16.8 \\
\hline & UG Late & 142 & 46.9 & 33 & 26.2 & 175 & 40.8 \\
\hline & PG Early & 11 & 3.6 & 31 & 24.6 & 42 & 9.8 \\
\hline & PG late & 19 & 6.3 & 26 & 20.6 & 45 & 10.5 \\
\hline \multirow[t]{4}{*}{ Field of study } & Arts and Humanities & 42 & 14.1 & 28 & 22.4 & 70 & 16.6 \\
\hline & Health and Social Care & 33 & 11.1 & 21 & 16.8 & 54 & 12.8 \\
\hline & Social Sciences & 144 & 48.5 & 31 & 24.8 & 175 & 41.5 \\
\hline & $\operatorname{STEM}(0)$ & 78 & 26.3 & 45 & 36.0 & 123 & 29.1 \\
\hline \multirow{6}{*}{$\begin{array}{l}\text { Highest parental } \\
\text { occupation }\end{array}$} & Manager & 77 & 26.0 & 38 & 31.4 & 115 & 27.6 \\
\hline & Professional & 117 & 39.5 & 57 & 47.1 & 174 & 41.7 \\
\hline & Manual/trade & 52 & 17.6 & 13 & 10.7 & 65 & 15.6 \\
\hline & Community/personal service & 22 & 7.4 & 6 & 5.0 & 28 & 6.7 \\
\hline & Clerical/administrative/sales & 13 & 4.4 & 6 & 5.0 & 19 & 4.6 \\
\hline & Other & 15 & 5.1 & 1 & .8 & 16 & 3.8 \\
\hline \multirow{7}{*}{$\begin{array}{l}\text { Student working } \\
\text { status }\end{array}$} & Full-time employed in role & & & & & & \\
\hline & related to targeted career & 29 & 9.4 & 22 & 17.5 & 51 & 11.8 \\
\hline & $\begin{array}{l}\text { Full-time employed in role } \\
\text { unrelated to targeted career }\end{array}$ & 27 & 8.8 & 8 & 6.3 & 35 & 8.1 \\
\hline & $\begin{array}{l}\text { Part-time employed in role } \\
\text { related to targeted career }\end{array}$ & 40 & 13.0 & 14 & 11.1 & 54 & 12.5 \\
\hline & Part-time employed in role & & & & & & \\
\hline & unrelated to targeted career & 115 & 37.5 & 29 & 23.0 & 144 & 33.3 \\
\hline & Not employed & 96 & 31.3 & 53 & 42.1 & 149 & 34.4 \\
\hline
\end{tabular}


Table 2 Factor structure and loadings for career values

$\begin{array}{llcc}\text { Value } & \text { Item } & \begin{array}{c}\text { Extrinsic } \\ \text { (Factor 1) }\end{array} & \begin{array}{c}\text { Intrinsic } \\ \text { (Factor 2) }\end{array} \\ \text { Status } & \text { It is important for me to have a high status job } & \mathbf{0 . 7 6 2} & -0.352 \\ \text { Social status } & \text { It is important for others to see me as having a } & \mathbf{0 . 7 3 2} & -0.364 \\ & \text { successful career } & & \\ \text { Job security } & \text { It is important that I have job security } & \mathbf{0 . 5 8 6} & 0.263 \\ \text { High earnings } & \text { It is important for me to attain high earnings } & \mathbf{0 . 7 7 5} & -0.213 \\ \text { Societal } & \text { It is important that I can make a good contribution } & 0.197 & \mathbf{0 . 6 8 0} \\ \text { contribution } & \text { to others' lives and society } & & \\ \text { Autonomy } & \text { It is important to be able to work autonomously } & 0.346 & \mathbf{0 . 5 0 7} \\ \text { Work-life } & \text { It is important to have a balance between work and } & 0.139 & \mathbf{0 . 6 9 4} \\ \text { balance } & \text { life } & & \\ \text { Challenge } & \text { It is important to do something which is challenging } & 0.276 & \mathbf{0 . 5 0 6}\end{array}$


Table 3 Regression analysis for extrinsic career values

\begin{tabular}{|c|c|c|c|c|}
\hline Variable & $\begin{array}{c}\text { Unstandardised } \\
\text { regression coefficient }(B)\end{array}$ & $\begin{array}{c}\text { Standard } \\
\text { error }\end{array}$ & $\begin{array}{c}\text { Standardised regression } \\
\text { coefficient }(\boldsymbol{\beta})\end{array}$ & $p$-value \\
\hline Constant & .656 & .281 & & .020 \\
\hline Gender & -.161 & .120 & -.078 & .179 \\
\hline Age & -.023 & .006 & -.191 & $.000 * *$ \\
\hline Residency & .262 & .132 & .109 & $.048 *$ \\
\hline Socio-economic status & -.070 & .108 & -.033 & .516 \\
\hline Institution & -.068 & .122 & -.032 & .578 \\
\hline $\begin{array}{l}\text { Stage of study - } \\
\text { undergraduate midway }\end{array}$ & -.025 & .158 & -.009 & .876 \\
\hline $\begin{array}{l}\text { Stage of study - } \\
\text { undergraduate late }\end{array}$ & .171 & .131 & .087 & .192 \\
\hline $\begin{array}{l}\text { Stage of study - } \\
\text { postgraduate early }\end{array}$ & .461 & .211 & .140 & $.030 *$ \\
\hline $\begin{array}{l}\text { Stage of study - } \\
\text { postgraduate late }\end{array}$ & .188 & .199 & .058 & .346 \\
\hline Health and Social Care & .073 & .173 & .026 & .673 \\
\hline Social Sciences & .077 & .131 & .039 & .557 \\
\hline Arts and Humanities & -.024 & .167 & -.009 & .884 \\
\hline$R^{2}$ & .089 & & & \\
\hline Adjusted $R^{2}$ & .060 & & & \\
\hline
\end{tabular}


Table 4 Regression analysis for intrinsic career values

\begin{tabular}{|c|c|c|c|c|}
\hline Variable & $\begin{array}{l}\text { Unstandardised } \\
\text { regression coefficient }(B)\end{array}$ & $\begin{array}{c}\text { Standard } \\
\text { error }\end{array}$ & $\begin{array}{c}\text { Standardised regression } \\
\text { coefficient }(\boldsymbol{\beta})\end{array}$ & $p$-value \\
\hline Constant & -.571 & .228 & & .013 \\
\hline Gender & .185 & .121 & .088 & .127 \\
\hline Age & .007 & .006 & .054 & .313 \\
\hline Residency & .157 & .133 & .065 & .237 \\
\hline Socio-economic status & -.192 & .109 & -.089 & .079 \\
\hline Institution & .410 & .123 & .191 & $.001 * *$ \\
\hline $\begin{array}{l}\text { Stage of study - } \\
\text { undergraduate midway }\end{array}$ & .153 & .160 & .057 & .338 \\
\hline $\begin{array}{l}\text { Stage of study - } \\
\text { undergraduate late }\end{array}$ & -.028 & .132 & -.014 & .830 \\
\hline $\begin{array}{l}\text { Stage of study - } \\
\text { postgraduate early }\end{array}$ & -.019 & .213 & -.006 & .930 \\
\hline $\begin{array}{l}\text { Stage of study - } \\
\text { postgraduate late }\end{array}$ & .094 & .201 & .029 & .642 \\
\hline Health and Social Care & .422 & .174 & .147 & $.016^{*}$ \\
\hline Social Sciences & -.014 & .132 & -.007 & .916 \\
\hline Arts and Humanities & .249 & .168 & .095 & .140 \\
\hline$R^{2}$ & .090 & & & \\
\hline Adjusted $R^{2}$ & .062 & & & \\
\hline
\end{tabular}

$* * p<.01 ; * p<.05$ 
Table 5 Regression analysis for career proactivity

\begin{tabular}{|c|c|c|c|c|}
\hline Variable & $\begin{array}{l}\text { Unstandardised } \\
\text { regression coefficient (B) }\end{array}$ & $\begin{array}{c}\text { Standard } \\
\text { error }\end{array}$ & $\begin{array}{c}\text { Standardised regression } \\
\text { coefficient }(\boldsymbol{\beta})\end{array}$ & $p$-value \\
\hline Constant & -3.977 & .534 & & .000 \\
\hline Gender & .134 & .109 & .065 & .218 \\
\hline Age & -.021 & .006 & -.173 & $.000 *$ \\
\hline Residency & -.004 & .121 & -.002 & .974 \\
\hline Socio-economic status & -.024 & .098 & -.011 & .809 \\
\hline Institution & -.091 & .112 & -.043 & .415 \\
\hline $\begin{array}{l}\text { Stage of study - } \\
\text { undergraduate midway }\end{array}$ & .098 & .144 & .037 & .496 \\
\hline $\begin{array}{l}\text { Stage of study - } \\
\text { undergraduate late }\end{array}$ & .006 & .118 & .003 & .959 \\
\hline $\begin{array}{l}\text { Stage of study - } \\
\text { postgraduate early }\end{array}$ & .158 & .193 & .048 & .413 \\
\hline $\begin{array}{l}\text { Stage of study - } \\
\text { postgraduate late }\end{array}$ & .164 & .180 & .051 & .362 \\
\hline Health and Social Care & .145 & .158 & .051 & .359 \\
\hline Social Sciences & .169 & .119 & .085 & .155 \\
\hline Arts and Humanities & .211 & .151 & .081 & .164 \\
\hline Extrinsic values & .457 & .068 & .315 & $.000 *$ \\
\hline Intrinsic values & .648 & .093 & .319 & $.000 *$ \\
\hline$R^{2}$ & .274 & & & \\
\hline Adjusted $R^{2}$ & .247 & & & \\
\hline
\end{tabular}

$* p<.01$ 
Table 6 Themes for factors influencing decision on which career to enter

Theme

Extrinsic factors

Intrinsic factors

Work role \& environment
Count

197

76
Count

$\begin{array}{cc}\text { Income } & 67 \\ \text { Job prospects } & 88 \\ \text { Status } & 12 \\ \text { Job security } & 20\end{array}$

Meaning and sense of purpose $\quad 92$

Alignment with personal values/beliefs $\quad 35$

Fulfilment and enjoyment $\quad 30$

Challenge and creativity 22

Work-life balance $\quad 16$

Passion/calling 92

Social and collaborative environment 14

Variety and responsibility $\quad 12$

Flexibility 12

Opportunity for travel 7

Location 12

Conditions and general environment 13

Employer credibility $\quad 6$

67
8
2
0
2
5
0
2
6
9
4
2
2
7
2
3
6

Field or industry of interest 71

Career goals 18

Learning and development 26

Strengths and capabilities 56

Work experience 57

Education and qualification $\quad 47$

Networks $\quad 77$

Formal 26

Informal 40

Not stated 11

Life experience $\quad 27$

Other 34 